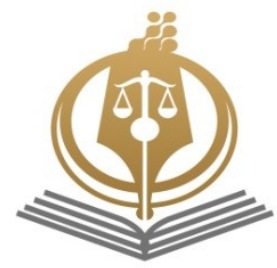

Interdisciplinary Legal Research

Jul 2020, 1(2): 35-49

Available online on: www. ilrjournal.ir

e-ISSN: 2717-1795

ORIGINAL RESEARCH PAPER

\title{
Ethical Considerations in Dealing with Terrorist Crimes in Iran And U.S. Law
}

Seyed Vali Noorashrafoddin ${ }^{1}, \quad$ Hasan Hajitabar Firoozjai ${ }^{2 *}$

Received:
23 May 2020
Revised:
23 my 2020
Accepted:
12 Jun 2020
Available Online:
01 Jul 2020

Keywords:

\section{Procedure,}

Social and Moral

Justice,

Terrorist Crime,

Security,

Public Order,

Ethics.

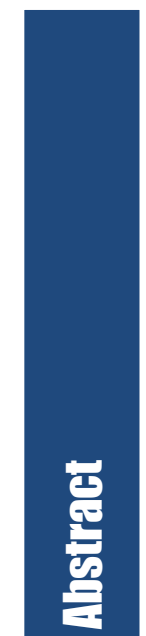

Background and Aim: Today, the spread of terrorism as one of the most important security challenges has led to an implementation of a discriminatory procedure; That is, the defendants of these crimes have been prosecuted in a different and more rigorous manner than other criminals, and some of the rights that other defendants enjoy are denied.

Materials and Methods: This is a descriptive - analytical Study.

Ethical Considerations: Honesty and confidentiality have been observed.

Findings: Implementing a discriminatory procedure for defendants of terrorist crimes is socially beneficial and is a moral choice; because by taking hard on defendants ensures the maintenance of public order and enhances the community security. It also provides the groundwork to prevent citizens from harms as a result of terrorist acts in the future .However, the restriction of individual liberties (such as the prolongation of temporary detention) and the deprivation of these defendants' rights over other criminals have led to unfair discrimination and question the judicial justice.

Conclusion: Discriminatory procedure of terrorist crimes defendants is an unethical, unjust and discriminatory choice. But it will be an ethical choice from the viewpoint of society as a whole and the need to maintain order and security of citizens.In both, the United States and Iran, the same approach of preferring the interests of society to the individual has been confirmed.

${ }^{1}$ PhD in Criminal Law and Criminology, Attorney at Law, Iran.

2 * Assistant Professor, Department of Law, Faculty of Humanity Science, Islamic Azad University, Qaemshahr Branch, Qaemshahr, Iran. (Corresponding Author)

Email:Hajitabar@yahoo.com Phone:+989112158173

Please Cite This Article As: Noorashrafoddin, SV \& Hajitabar Firoozjai, H (2020). "Ethical Considerations in Dealing with Terrorist Crimes in Iran And U.S. Law”. Interdisciplinary Legal Research, 1 (2): 35-49. 
مقاله هُروهشى

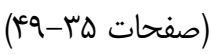

\title{
ملاحظات اخلاقى مربوط به دادرسى جرايم تروريستى در حقوق ايران و آمريكا
}

\author{
سيد ولى نور اشرفالدين'؛ حسن حاجىتبار فيروزجايى׳ \\ 1. دكترى حقوق كيفرى و جرمشناسى، وكيل دادگّترى، ايران.

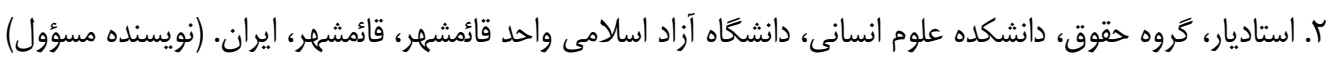

Email: Hajitabar@yahoo.com

دريافت: س/ץ/\%

زمينه و هدف: امروزه كَترش تروريسم به عنوان يكى از مهمترين خالشهاى امنيتى، موجب معرفى و اجراى دادرسى افتراقى شده است؛ بدين معنا كه متهمان اين جرايم، به شيوه اى متفاوت و سخت گيرانهتر نسبت به ساير مجرمان مورد تعقيب و رسيدگى قضايى قرار گرفته و بخشى از حقوقى كه ساير متهمان از آن برخوردار مىباشند از ايشان سلب مى كردد. هدف از يثوهش ييش رو تبيين و شناخت مؤلفهاى اخلاقى، مصاديق و جلوههاى اخلاقمدارانه در خصوص دادرسى جرايم تروريستى از منظرى تطبيقى ميان حقوق كيفرى دو كشور ايران و آمريكا است. مواد و روشها: روش تحقيق ما در اين بزوهش، توصيفى - تحليلى است. ملاحظات اخلاقى: در به سامان رسيدن اين تحقيق ضمن رعايت اصالت متون، صداقت و امانتدارى رعايت شده است.

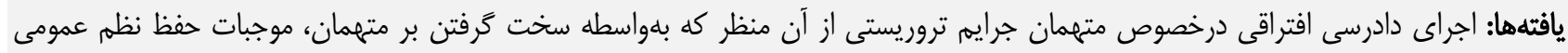

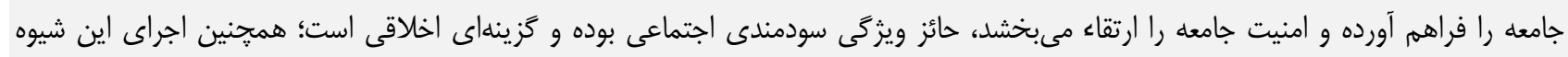

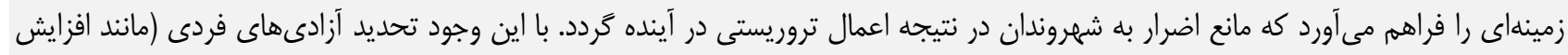

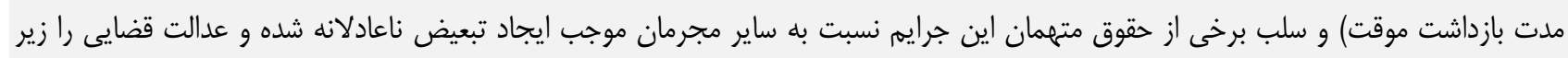

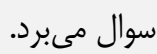
نتيجهكيرى: دادرسى افتراقى متهمان جرايم تروريستى از نغاه فرد محور، گزينهاى غير اخلاقى و ناعادلانه و تبعيضآميز است؛ ليكن از منظر توجه به

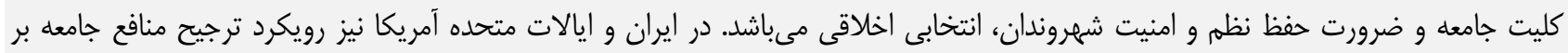
فرد مورد تاييد قرار كرفته است. كلمات كليدى: دادرسى، عدالت اجتماعى و اخلاقى، جرايم تروريستى، امنيت، نظم عمومى، اخلاق. 
متنوع شدن اشكال آن است كه گَونهاى مختلف از آن در تقسيم بندىهاى متفاوتى از حيث ارتكاب و انخيزه قابل

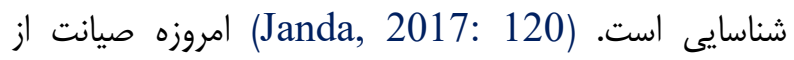
ارزشهاى بنيادين جامعل از جمله امنيت، در قالب دكترين امنيت ملى، به ضرورتى ترديدنايذير تبديل شده است؛ به كَونهاى كه گَترش نامنى داخلى (از جمله نامنىهاى داخلى مى توان به حمله تروريستى داعش به ساختمان مجلس شوراى اسلامى در سال عوسا در تهران نام برد) و بينالملى ناشى از ابعاد و اشكال مختلف تروريسم از حيث نحوه ارتكاب و انخيزه شامل تروريسم هستهاى، بيو تروريسم، تروريسم ملى تروريسم سياسى، تروريسم نظامى، تروريسم مذهبى، تروريسم دولتى، سايبر تروريسه، تروريسم كشاورزى، تروريسم شيميايى، تروريسم جنايى و... باعث شده است تا در سياستخذارىهاى جنايى داخلى و بينالملى به فكر ايجاد تدابير خاص و ويزه در

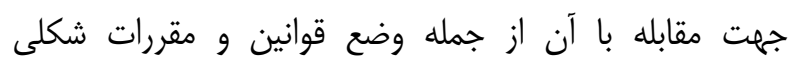
افتراقى يا آيين دادرسى كيفرى افتراقى بنمايند. با توجه به

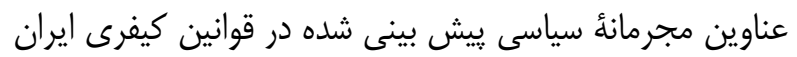
(ماده r قانون مبارزه با تامين مالى تروريسم اصلاحى سال Vوץ") كه همان مصداق جرايم تروريستى مىباشد، نيازى به تخصيص عنوان خاصى به اعمال تروريستى تحت عنوان جرايم تروريستى نيست. در واقع، مفهوم تروريسم، مفهوم جديدى محسوب نمى شود و اعمال تروريستى، خواه ناخواه به عنوان يكى از جرايم عليه اشخاص يا جرايم عليه اموال و يا جرايم عليه امنيت و آسايش عمومى مطرح مى بديهى است سخن كَفتن از اعمال تروريستى، به نحو محسوسى همان مفهوم و مصاديق جرايم تروريستى را در بر دارد. (قربانى،

(I)V:I)qq

اهداف نغارنده از نغارش يزوهش ييش رو، تبيين و شناخت مؤلفهها و معيارهاى اخلاقمدارانه در دادرسى جرايم تروريستى برونى در دو كشور ايران و آمريكا بوده و همجِنين شناخت مصاديق و مونى جلوههاى اخلاق محور در جرايم تروريستى و شناسايى موانع و خلأهاى قانونى در راستاى دادرسى اخلاقمدارانه نسبت به جرايم تروريستى در حقوق كيفرى ايران و آمريكا مىباشد. از
مقدمه

ا- بيان موضوع: حقوقدانان معاصر مهمترين وابستخى حقوق جزا به علوم انسانى را مربوط به علم اخلاق مىدانند. كاه رعايت نكردن مقررات اخلاقى واكنش خفيف اجتماعى را به دنبال دارد كه بلطور معمول با نكوهش، سرزنش و توبيخهاى اخلاقى خفيفى همجون بىاعتنايى همراه است، اما اتر به دليل اهميت برخى از مقررات اخلاقى، عكسالعمل شديد باشد مجازات يا اقدامهاى تأمينى ياسخكَوى عمل ضد اخلاقى است كه عنوان جرم مى گيرد. اگر همانند برخى حقوقدانان نخواهيه

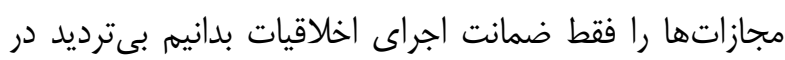
كنار ضرورتهايى كه قانونخذار را وا مىدارد تا قوانينى مورد نياز

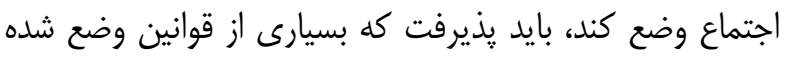

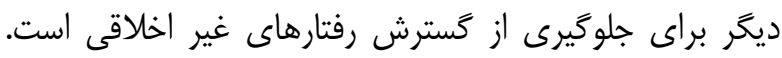
يس بهاطور اختصار در مورد مفهوم يديده مجرمانه و نسبت آن با اخلاق مىتوان كفت هر جند رايجترين تعريف از جرم، نسبت به كنشهاى مخالف نظهم اجتماعى انجام مىشود اما با نخاهى دقيقتر مىتوان كَفت بىترديد همين مفهوم نظم اجتماعى بدون توجه به كرايشهاى اخلاقى يك جامعه قابل اشاره نيست. از ديخر سو، رابطه بين اخلاق و حقوق امرى مسلم و مورد تأييد و تأكيد فلاسفه و انديشمندان اخلاقى و حقوقدانان بين إنان است. از جمله مباحثى كه به طور خاص مىتوان رابطه اين دو لو

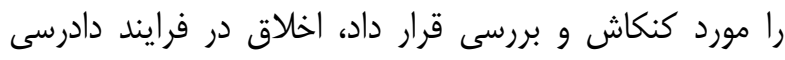

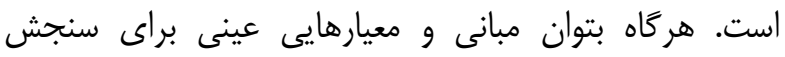
رعايت عدالت در يك دادرسى ارائه نمود، مىتوان راجع به هيه اجراى عدالت در مرحله رسيدگى اظهارنظر دقيقترى كرد. مبانى اخلاقمدارانه از اين منظر شامل، تضمين براى برخوردارى افراد از حقوق اساسى خود، از جمله حق حيات،

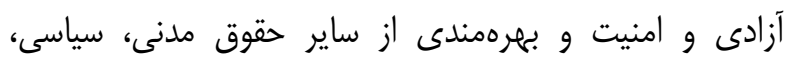
فرهنگىى، اقتصادى و اجتماعى مىباشد. در نتيجه بايد

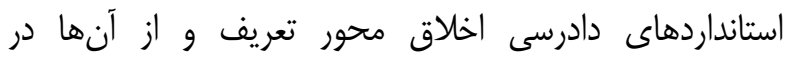
سنجش عادلانه بودن استانداردها استفاده شود. امروزه تروريسم به عنوان يكى از مهمترين جالش امنيتى در سطح بينالمللى و داخلى محسوب مىشود. يكى از ييامدهاى گسترش تروريسه، 
بينالملىى مى كند يا زيرگروههاى مهمى دارد كه اقدام به

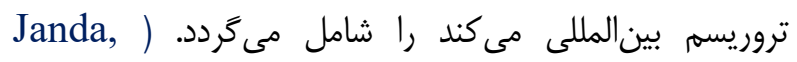
2017: 121 علاوه بر قوانين فوقالذكر، قانون جزاى نمونه

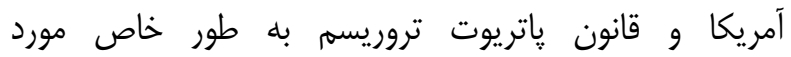
جرمانغارى قرار گرفته است. در ياسخ به اين سوال كه آيا در نظام حقوق كيفرى موضوعه

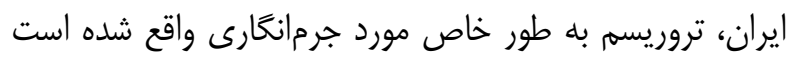
يا خير؟ بايد كفت كه نظرات و ديدكاههاى متفاوتى ميان دكترين حقوقى وجود دارد. به اعتقاد برخى در نظام قانونگذارى ايران با سكوت و خلأ قانونى در باب جرايم تروريستى مواجه

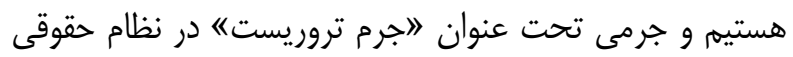

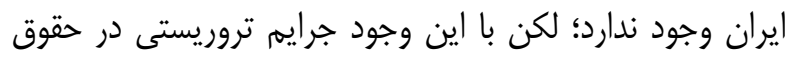
و رويه قضايى ايران را مىتوان در قالب عناوين مجرمانه ديخَى مانند محاربه، افساد فى الارض، بغى، خرابكارى در در تأسيسات عمومى و امثالرهم شناسايى و تحت تعقيب قرار داد. (Konani, 2015:40) در مقابل كروهى از جمله نكارندًان اين مقاله قائل به اين نظرند كه در نظام قانونكذارى ايران

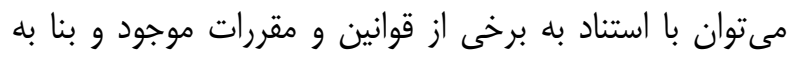
استدلال ها و توجيهات ذيل يذيرفت كه "جرايم تروريسم" نيز

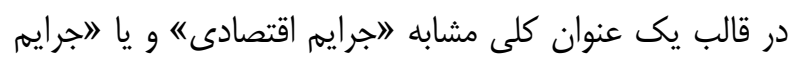
سياسى" در حقوق ايران به طور خاص نيز مورد جرمانغارى قرار كَرفته است؛ به گَونهاى كه اين امر يعنى جرايم تروريستى در ماده r قانون مبارزه با تأمين مالى تروريسم اصلاحى سال

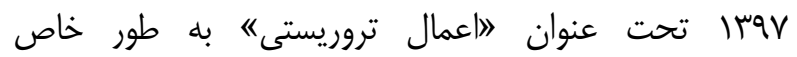

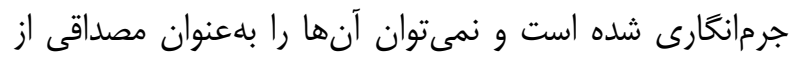
جرايم در حكم محاربه و يا افساد فى الارض تلقى نمود.

(Konani, 2015:40)

r- روش تحقيق: در اين مطالعه تحليلى، اسناد و قوانين مربوط به شيوه برخورد با متهمان جرايم تروريستى و نيز مقالات منتشره، بلصورت هدفمند جستجو شده و توجيهات اخلاقى

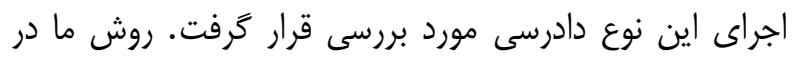
انجام اين يزوهش بلصورت توصيفى - تحليلى بوده است.
اين رو، نكارنده در يى ياسخ به سوالاتى از قبيل مهمترين

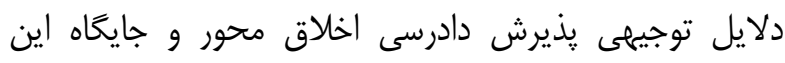
تفكر در جرايم تروريستى و همجنين مصاديق و رابطه ميان ادله اثبات جرايم تروريستى و اخلاق، مىباشد.

r- تبيين مفاهيم: ترور و تروريسم وازههايى است كه از فرهنَ غرب وارد مجموعه وازَّان زبان فارسى شده است بلهورى كه حتى در برخى از فرهنكَهاى معتبر لغت فارسى مانند فرهنگ معين يافت نمى شود. خواستخاه اين وازهها فرهنَ غرب است كه در آنجا داراى بستر تاريخى خاص و ونس

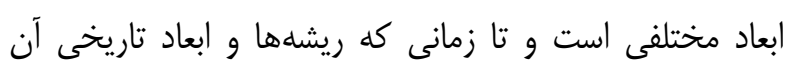

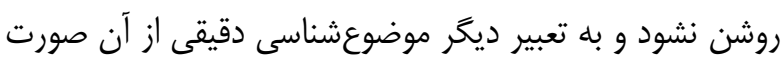
نيذيرد، نمىتوان از رويكرد اسلام نسبت به آن سخن به ميان

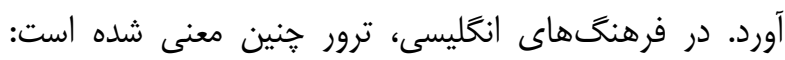

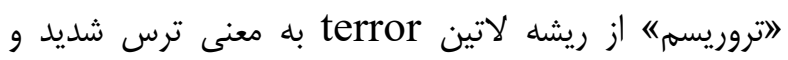
وحشت است. (Gordon, 2016:77) برخى از لغت شناسان در توضيح كلمه ترور קنين آوردهاند: اترور مأخوذ از فرانسه و به معنى قتل سياسى به وسيله اسلحه است و در فارسى متداول شده است. اين كلمه در فرانسه به

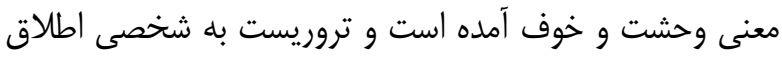
مىشود كه با اسلحه مرتكب قتل سياسى شود. تروريسم در زبان فارسى به اصلى كفته مىشود كه در آن از قتلهاى سياسى و ترور دفاع گرددها. (Kavanagh, 2017:90) تروريسم يعنى خشونتهاى سيستماتيك كه كَروهى از افراد را دجار رعب و وحشت نمايد. تروريسم از نظر مفهوم حقوقى عبارت است از اقدامات جنايى بر ضد كشور به منظور ايجاد ترس در اشخاص، كه اين اقدامات با توسل به قتل و خرابكارى انجام مىشود و گروه زيادى از مردم در اين عمليات كشته اله مىشوند. (Dain, 2017:89)

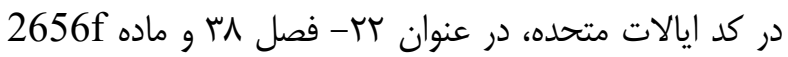
تروريسم و گروه تروريستى اين طور تعريف شدهاند: تروريسم به معناى ارتكاب خشونت از ييش انديشيده، با انخَيزه سياسى عليه اهداف غير رزمى توسط گروههاى فرعى ملى يا عوامل مخفى است و گروه تروريستى هر گروهى كه اقدام به تروريسم 
شهروندان نيز دقيقاً از همين جا ناشى مىشود. به عبارتى بهتر، قواعد آيين دادرسى كيفرى با هدف قانونمند كردن اعمال

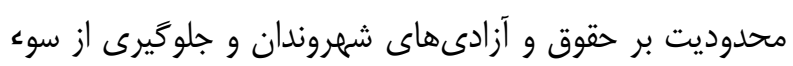
استفاده مقامات حكومتى از قدرت عليه شهروندان وضع

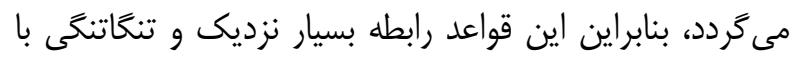
حقوق و آزادىهاى فردى دارند. (محمودى، عوس إ: عبر)

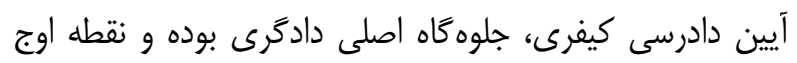
نمايش انسانيت در فرايند دادرسى كيفرى تبلور مىيابد. حتى دئى آنخاه كه مرتكبان جنايتهاى عليه بشريت، نسل كشى و و جنايتهاى جنكَى، به عنوان متهم در برابر دستخاه عدالت

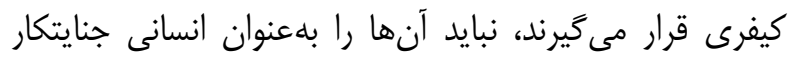
ديد بلكه بايد به آنها همجيجون انسانى كه از حقوق برخوردارند

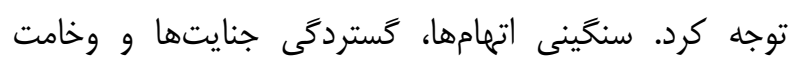
اعمال ارتكابى هيجًاه مجوزى براى برخوردهاى غير انسانى با متهم محسوب نشده و برقرارى نظم و امنيت، هرجند كه برهم خوردن آن، موجبات يريشانى افكار عمومى را در حد كسترده اى فراهم كند، نمىتواند كنشهاى غير انسانى و خارج از قواعد آيين دادرسى كيفرى خط بطلانى بر مدار انسانيت را توجيه

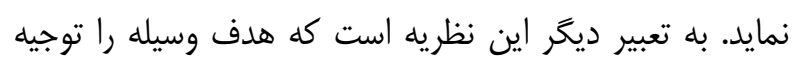

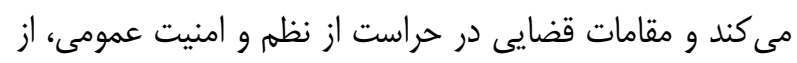
هر قيد و بندى رها هستند از اين رو، در توصيف مقررات آيين

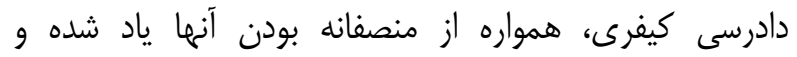

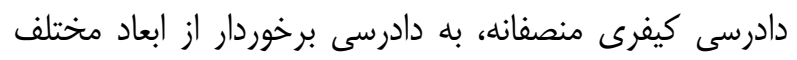
حقوق دفاعى متهم تعبير مىشود كه برگرفته از آموزهاى

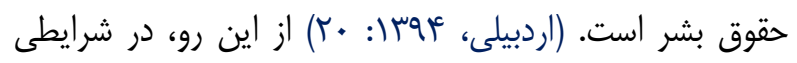

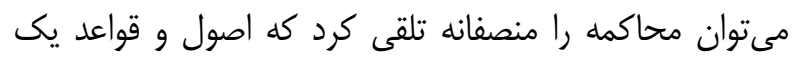
نظام مترقى بر جريان دادرسى حاكم بوده و متهمه در شرايطى ملى

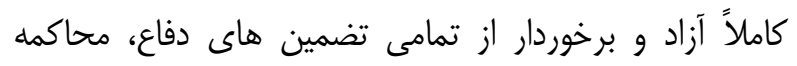

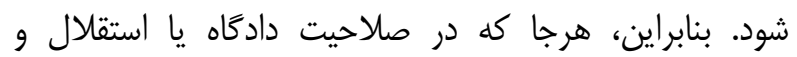
بىطرفى آن ترديد باشد، يا حقى از حقوق متهم ناديده گرفته شده باشد، به يقين محاكمه را بايد غيرمنصفانه به شمار آورد.

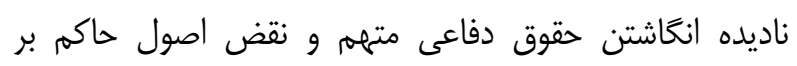

بحث و نظر

\section{ا- جايكاه ملاحظات اخلاقى در قانون آيين دادرسى جرايم}

تروريستى

اصل كرامت انسانى و اخلاقى در قلمرو حقوق كيفرى شكلى نيز از جايگاه والايى برخوردار بوده و داراى نقش محورى و وراسى بنيادين است. اين اصل در تضمين مشروعيت نظام دادرسى لهى

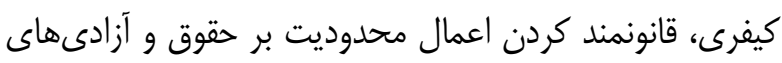
اساسى شهروندان، جهانى شدن حقوق كيفرى و تعديل حاكميت كيفرى مطلق و انحصارى دولتها داراى اهميت و نقش اساسى است. (محمودى، عهبו: هـ) به عبارتى ديكر احترام به كرامت انسانى و حقوق و آزادىهاى افراد از مبانى اخلاقى-سياسى مشروعيت يك نظام سياسى

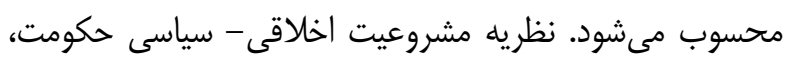

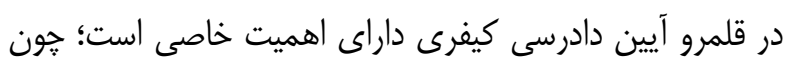

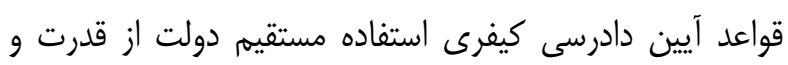
خشونت عليه شهروندان را سازماندهى و كنترل مى كند. اگر قواعد آيين دادرسى كيفرى ظالمانه و خودسرانه بوده و به دولت

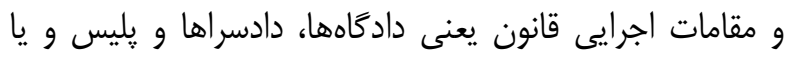
حتى اشخاص عادى اجازه استفاده از شيوهها و تدابير خودسرانه

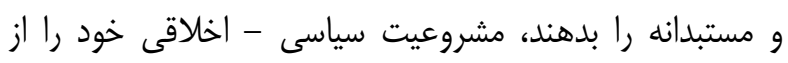
دست خواهند داد. اين گَونه اقدامات باعث سلب اعتماد مردم به حكومت گرديده و موجب خواهند شد كه نظام كارايى خود را از دست بدهد هراكه يكى از ويثگى هاى اساسى يك نظام حقوقى -سياسى كارامد اقدرت توجيهى" آن است. جنانكه ملاحظه مىشود، قوانين آيين دادرسى كيفرى بهترين وسيله براى شناخت ماهيت نظامهاى سياسى بوده و درجه آزادمنشى يكى سيستم سياسى -حقوقى را مشخص مى كنند. ) Jazaiery,

در واقع ااصل حاكميت قانون" كه خود مبتنى بر احترام به

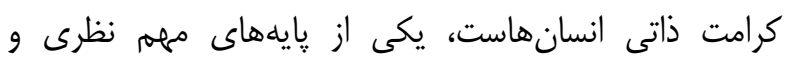

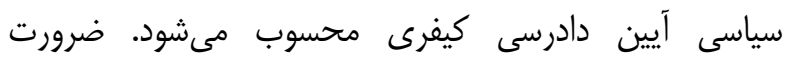

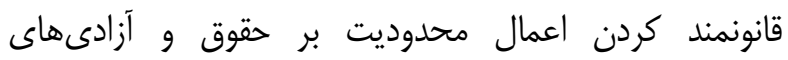


توجـهـ بسـيار زياد به حقوق و آزادىهاى فردى و حفظ كرامت اخلاقى شخصى، موجب غفلـت از مصالح و منافع

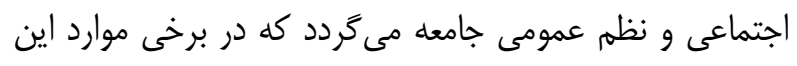

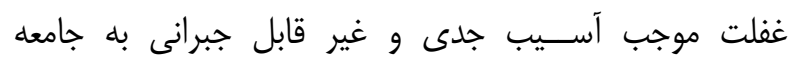

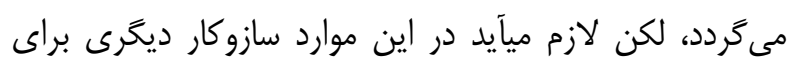
حفظ حقوق و امنيت جامعل و سودمندى اخلاقى جامعوى

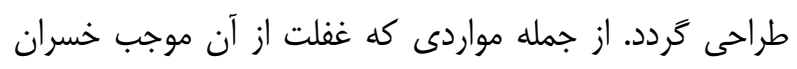

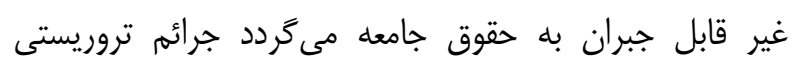

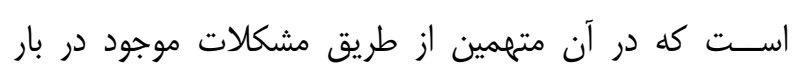

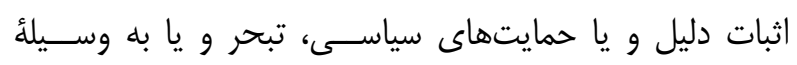

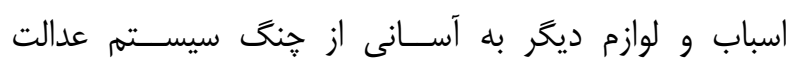

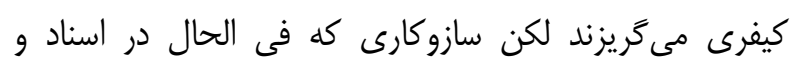

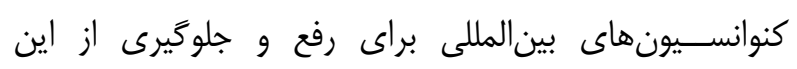
مشـكل بيش بينى كرديده است تسـهيل نمــودن بار اثبات دليل و معاف كردن مقــام تعقيب به تكليفى كه براى ارائه

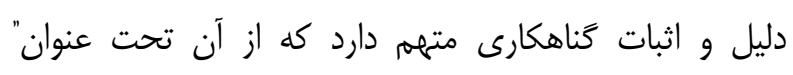

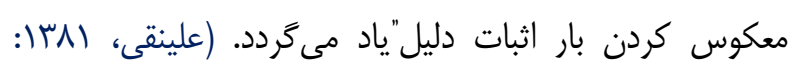

در قانون موضوعهُ ايران مواردى مشاهده مى گردد كه مقنن در

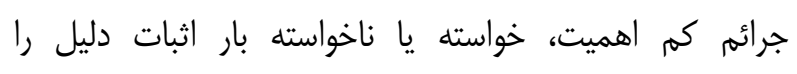

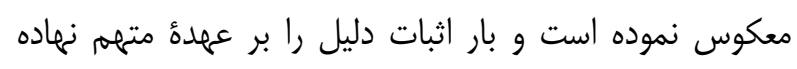

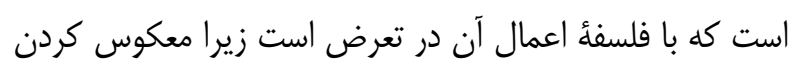
بار اثبات دليل بايد تنها در جرايم مهم كه به شدت به به حيل ديات

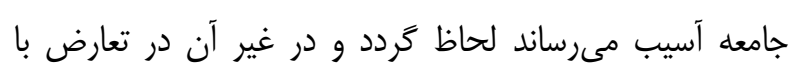
حقوق و آزادى افراد بوده كه توجيه يذير نمىباشـــــ لذا توصيه

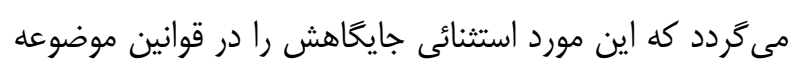

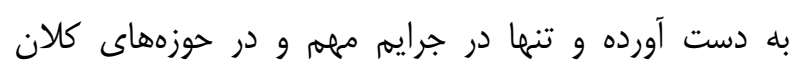
اقتصادى، سياسى، اجتماعى، فرهنگى و غيره، ملحوظ گرددد.

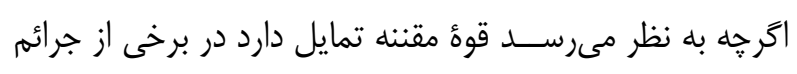

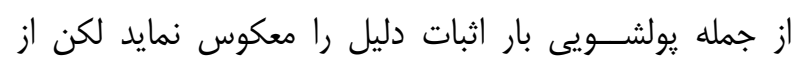

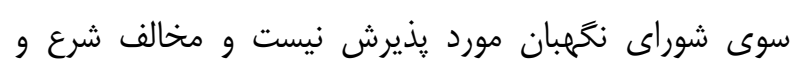

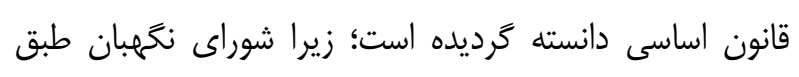

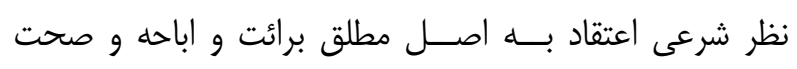

دادرسى منصفانه، كاه در قالب قانونگذارى تحقق مىيابد و كاه از رهگذر تدابير اجرايى و اقدامهاى عوامل اجرايى انجام

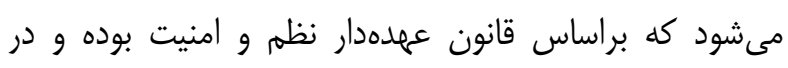

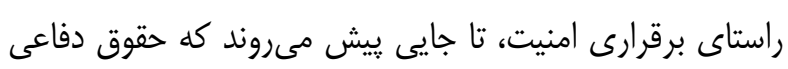

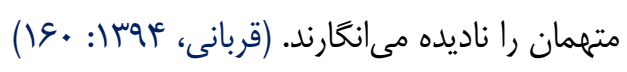

r- جلوههاى دادرسى كيفرى افتراقى جرايم تروريستى با تاكيد بر ملاحظات اخلاقى و دادرسى منصفانه در حقوق ايران و آمريكا در ذيل نغارنده به منظور درى دقيق و همه جانبه موضوع در رويكرد تطبيقى، به تبيين جلوههاى دادرسى افتراقى جرايه تروريستى در حقوق ايران و امريكا مى يردازد. r-1 ادله اثبات جرايم تروريستى و اخلاق ץ-1-1 معكوس شدن بار اثبات دليل و جايكاه اصول اخلاقى در آن از جمله قواعد و اصولى كه تحقّق يك دادرسى منصفانه و اخلاقمدار را تضمين مى كند، فرض بى خناهى است. التزام به له

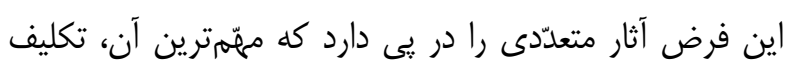

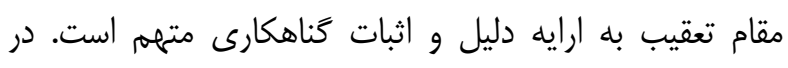

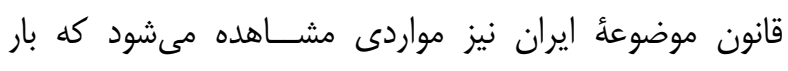

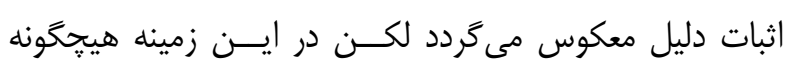
نظهبندى خاصى وجود نـــارد زيرا معكوس كردن بار اثبات

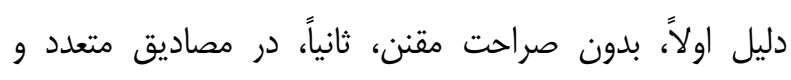

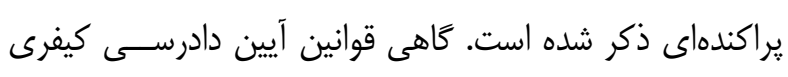

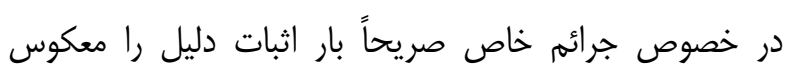

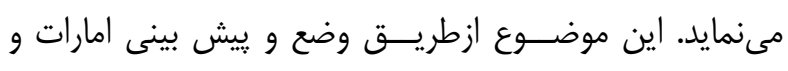
فروض قانونى به عمل مى آيد و كاهى مقنن به دستخاه قضائى اجازه مىدهد به صلاحديد خود ضمن بررسى قرائن موجود

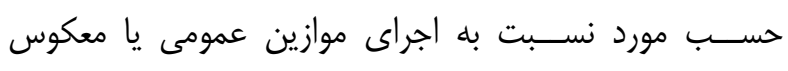
كردن بار اثبات دليل اقدام نمايد. به عبارت ديخر، قوانين آيين دادرسى كيفرى از سازوكارى استفاده مى كند كه تفويض اختيار

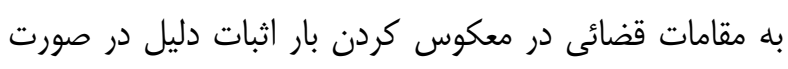
وجود قرائن به تأسيس يكى اماره قضائى مىيردازند. 
دهنده از رهخذر آن خود را بزهكار مى داند. خود مجرميندارى راهكارى براى كوتاه كردن فرايند كيفرى از طريق ايجاد شرايطى براى يذيرش ارادى اتهام از سوى متههم است

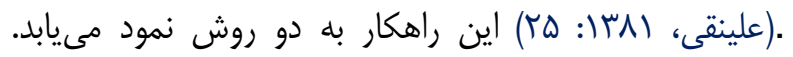
بلهور مستقيم كه با بازجويى بازيرس يا دادستان يا شخص

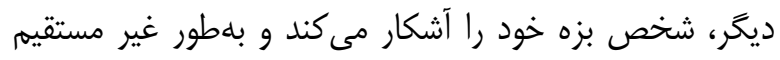

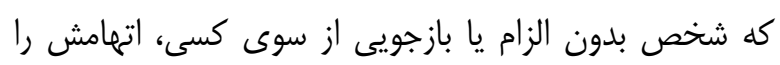

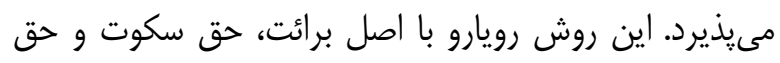
مصونيت است اما برخى بر اين باورند كه متهم منبع و دليل نخستين براى اثبات اتهام به شمار مىرود و ينهان كردن بزه نه تنها به زبان متهم و باعث سرگردانى وى در طول

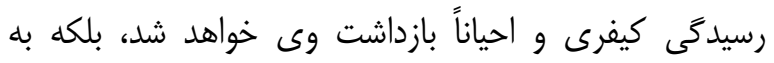

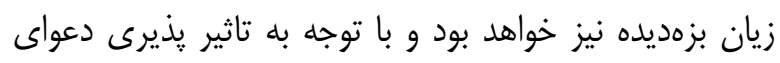

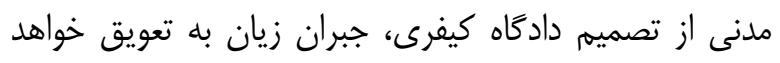
افتاد. علىرغم اينكه در بسيارى از كشورها اصل مصونيت در برابر خود مجر ميندارى يذيرفته شده ولى در ارتباط با متهم به بزه تروريستى، اين شيوه در دادكاههاى برخى كشورها اجرا مى گردد. (Geoff, 2015:45) در سيستم قضايى انغخلستان

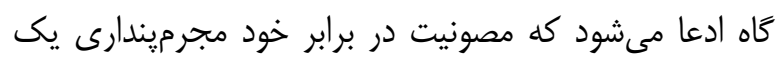
حق بنيادين نبوده و بلكه محدوده و جايگاه آن نيز يوشيده است و در جايى كه سود همكانى اقتضا كند به ويزه در بييكار

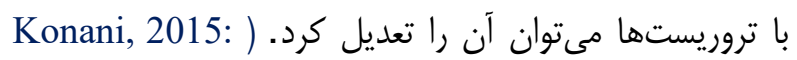

\section{r-I-Y- يذيرش معامله اتهام در يرتو دادرسى اخلاقمدار}

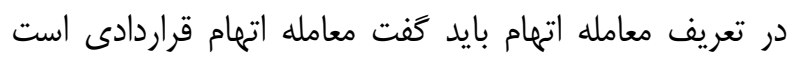
فى مابين مقام تعقيبكننده جرم و متهم كه هر دو طرف ملزم

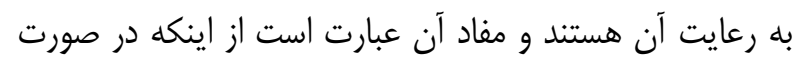
اعتراف متهمم به جرم يا كيفيات مشدّده آن ناديده كرفته مىشود

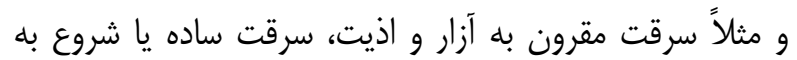

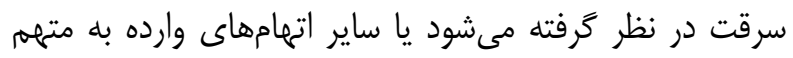

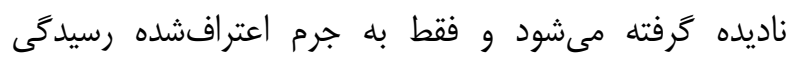
مى گردد و يا اخر فقط يك اتهام مورد تحقيق باشد، اعتراف
وغيره دارد لكن براى رفع اين مشـكل و اعمال معكــوس د.

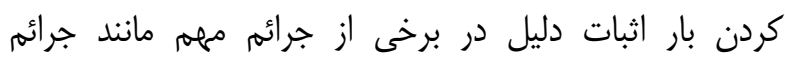

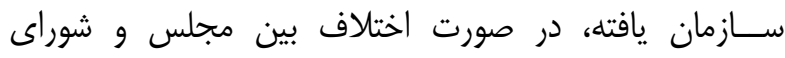

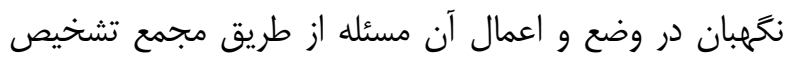
مصلحت نظام مرتفع خردد. اگرجه قانون اساسى ايالات متحده به صورت مرده آشكارا اصل

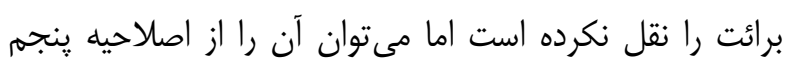
(اصلاحيه شماره ه: هيج شخصى به سبب ارتكاب جرم

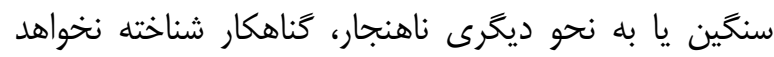

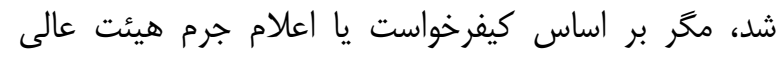
منصفه، مكر در موارد مربوط به نيروهاى زمينى، دريايى يا

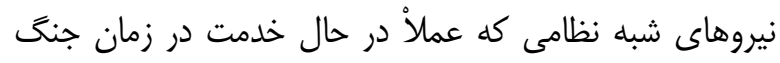

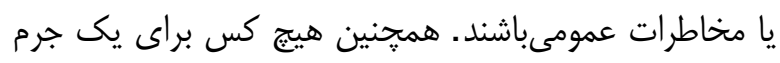

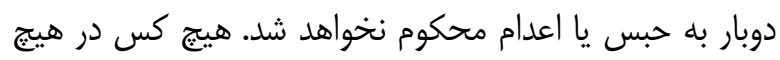
مورد كيفرى به اقرار به تخلف خود مجبور نمىشود، و هيجكس بدون طى مراحل قانونى مقتضى از حق زندگى، آزادى و دارايى خويش محروم نخواهد شد. همجنين اموال خصوصى افراد بدون يرداخت غرامت عادلانه براى استفاده

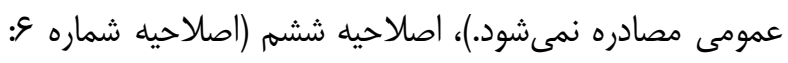
در تمامى دادرسىهاى كيفرى، مترمه از حق محاكمه سريع و علنى توسط هيئت منصفهاى بى طرف از ايالت و منطقهاى كه جرم در آن رخ داده برخوردار است، منطقه مذكور بايد ييشاييش از سوى قانون تعيين شده باشد، وى همجنين از

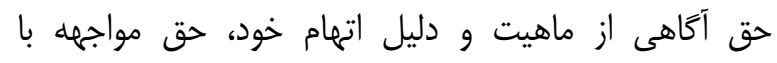
شهودى كه عليه وى شهادت مىدهند، داشتن وقت و امكان لازم جهت احضار شهود به نفع خود، و داشتن وكيل به منظور دفاع از خود برخوردار است) و نيز اصلاحيه جِهاردهم استنباط كرد. (Silver, 2016: 100) همجنين قاضى در يرونده كافين در برابر ايالات متحده اصل برائت فرد متهم را صادر نمود و بر

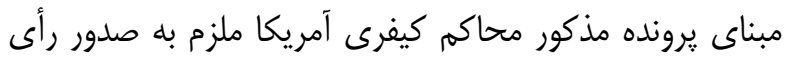

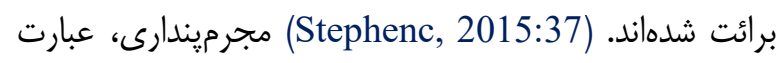
است از بيان سخنان يا دادن مدركهايى كه گَوينده يا ارايه 
گيرد مخر بر مبناى دليل محتمل. در يرونده برينكار در برابر

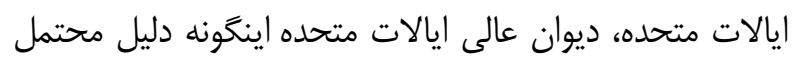
را معنى كرد: "اضعيتى كه حقايق و مستندات مدنظر مأمور قضايى و اطلاعات موثق مبنى بر ارتكاب جرم كفايت مى كندها.

(Gordon, 2016: 70)

در حقوق كشور آمريكا يكى از طرق شناسايى و كشف مرتكبان

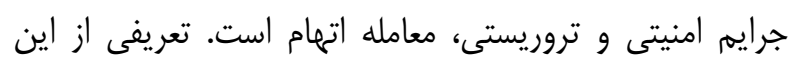

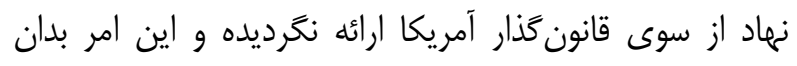
دليل است كه نه مخالف حقوق فدرال محسوب مى گردد و نه از حقوق شهروندان ايالات متحده به حساب مى آيد. در نتيجه، معاله

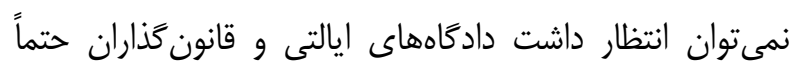

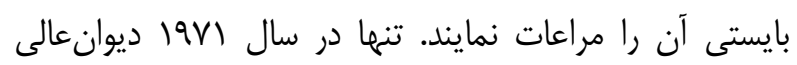

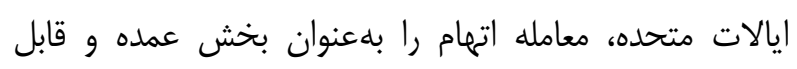
قبول نظام كيفرى يذيرفته است. درخصوص فوايد معامله اتهام

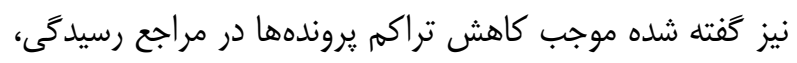
كاهش ريسكيذيرى با توجه به عدم اطمينان از سرنوشت و و

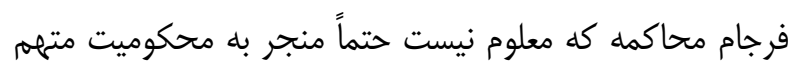

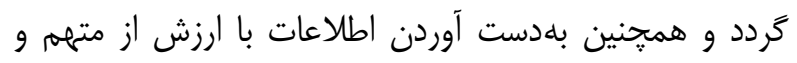
عوامل ارتكاب جرم و نحوه وقوع آن از جمله فوايد معامله

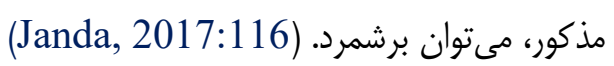
معامله اتهام يكى از نهادهاى بسيار كاربردى در ايالات متحدون بهرد است. اكثريت قاطع يروندههاى كيفرى به نسبت محاكمه هيأت منصفه به واسطه معامله اتهام حل و فصل مى شوند. همجنين

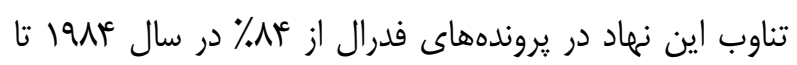

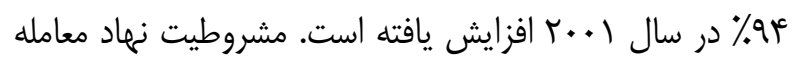

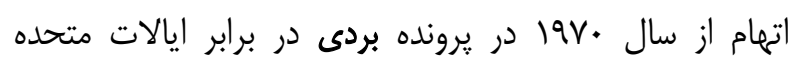

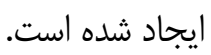

قاعده رد ادله مانع استفاده دولت از دلايلى كه به واسطه نقص قانون اساسى به دست آمدهاند مىشود. يرونده امب در برابر

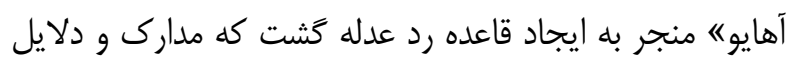
به دست آمده از طريق جستجو و بازداشت غيرمنطقى و بدون ايجا دليل محتمل باعث نقص اصلاحيه جهارم قانون اساسى شده

بود. (Browntie, 2016:20)
متههم باعث كاهش در ميزان مجازات مىشود. بدين ترتيب در

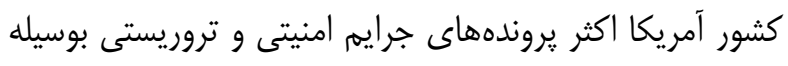

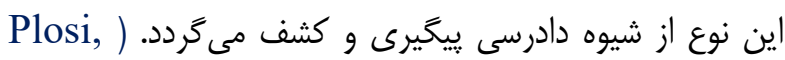
(2019: 60 اگرجه گرو كشى و معامله اطلاعات از منظر اخلاقى مذموم و

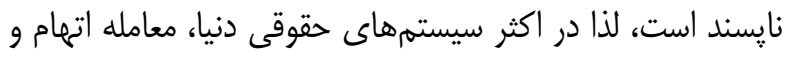
كروكشى با متهم از سوى مقام تعقيب امرى عادى و معمول

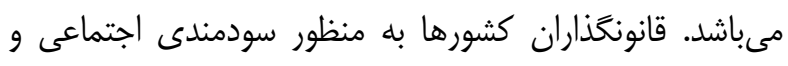
با در نظر گرفتن فايده جمعى، اخلاق اجتماعى را بر اخلاق فردى مقدم دانسته و معامله اتهام را مجاز مى دمانند. (Kittichisaree, 2018: 75) در نظام حقوقى ايران معامله اتهامى يك تأسيس سازشى براى

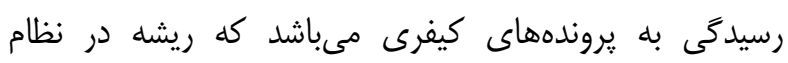

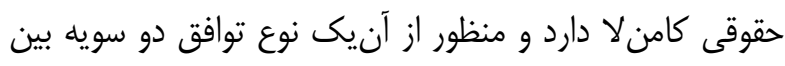

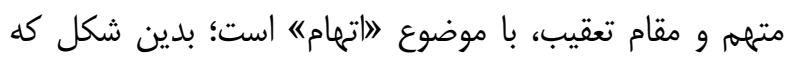

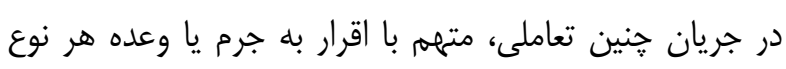
همكارى ديكر، مقام تعقيب را يارى مىدهد و در مقابل، مقام

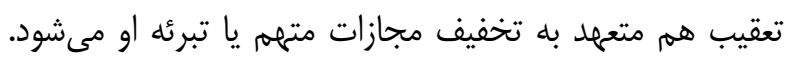
از مزاياى اين نهاد كمكى است كه در تسريع امر دادرسى و

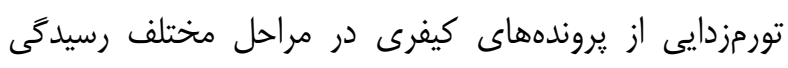
مى كند؛ جنين تأسيسى در نظام حقوقى كشور ما وجود ندارد اما

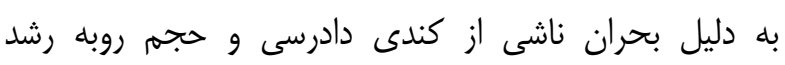
يروندههاى امنيتى در نظام حقوقى ما، بررسىاين نهاد و مزايا و

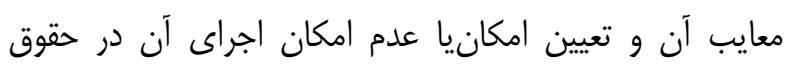
كشور ما خالى از فايده نيست. در ايالات متحده بر اساس اصلاحيه جهارم (اصلاحيه شماره ثا: حق مصونيت اشخاص به صورت فردى، در خانه، در نامهها،

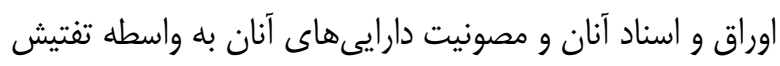
و توقيف غير موجه نبايد مورد تعرض قرار گيرد، و هيج حكمى ونى

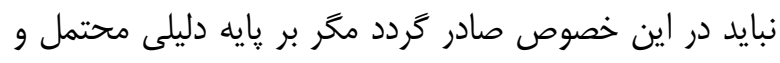

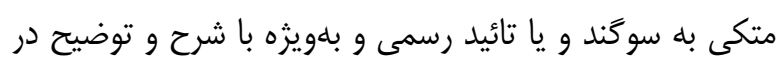

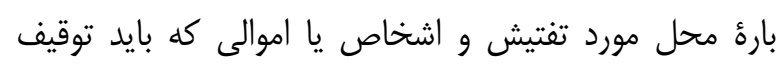
شوند) قانونى اساسى حق مصونيت افراد نبايد مورد تعرض قرار 
بايست وجه دوم آن را نيز در نظر داشت كه اگر دادرسى جرايم تروريستى بلصورت علنى برگزار گردد، باب يادگيرى افراد ديخر

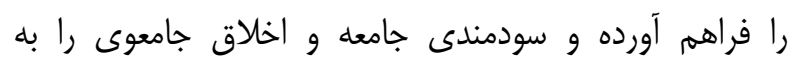
مخاطره مىاندازد. از طرف ديخر اخلاق حكم مىنمايد كه

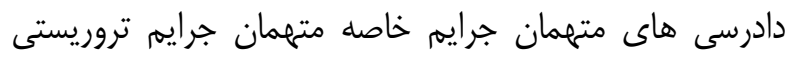
بلهورت علنى برَزار گردد تا ارعاب و جنبه سودمندى كيفر در ميان افراد جامعه موثر واقع شود. بدين ترتيب اجراى دادرسى بـ برديه غير علنى اگرجه حقوق فردى را تحت تاثير قرار داده و كرامت ذاتى انسانى را نشانه كَفته و همجنين موجبات نقض حقوق شهروندى افراد و تزلزل مبانى دادرسى اخلاق محور را فراهم مى آورد، لكن به منظور حفظ اصول و مبانى اخلاق جامعوى به له

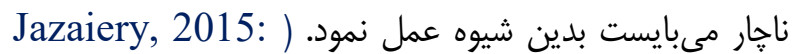

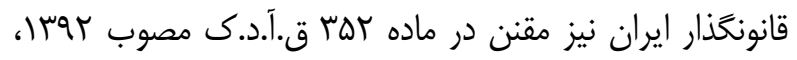
در اين باره بيان داشته كه محاكمات دادكاه علنى است، مكر در جرايم قابل كذشت كه طرفين يا شاكى، غيرعلنى بودن محاكمه را درخواست كنند. همجنين دادكاه پِ از اظهار عقيده دادستان، قرار غيرعلنى بودن محاكم را در موارد زير صادر

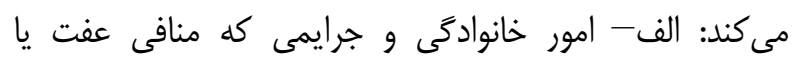
خلاف اخلاق حسنه است. ب - علنى بودن، مخل امنيت عمومى يا احساسات مذهبى يا قومى باشد. (قربانى، عوسا:

(I)

r-r- رعايت حقوق شهروندى و اخلاق r-r-ו- بازداشت خودسرانه توسط دولت در حقوق ايران و آمريكا و جايكاه اخلاق در آن

در برخى از جرايم همانند جرايم ترويستى به واسطه اهميت آن آن إنهان و به منظور جلوكيرى از فرار متهمين اينگونه از جرايم، مقنن امكان جلب قبل از ارسال احضاريه را با مقرر نمودن بند اته ماده •11 قانون آيين دادرسى كيفرى مصوب זوجا مورد تاكيد قرار داده است. ماده مذكور در اين باره بيان مىدارد: ادر موارد زير بازيرس مىتواند بدون آنكه ابتداء احضاريه فرستاده باشد،

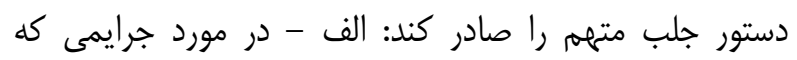

r-r - برابرى سلاح و دادرسى منصفانه

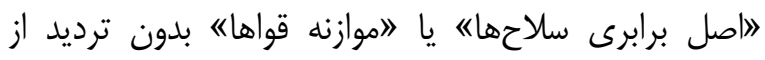
عناصر ذاتى و غيرقابل تفكيك دادرسى عادلانه و اخلاق محور است. از آنجا كه در فرآيند دادرسى كيفرى مقام تعقيب به له

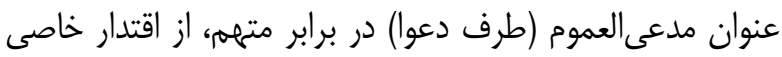
برخوردار است و به راحتى مىتواند از قواى عمومى و ساير

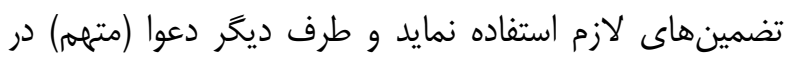
جنين موقعيتى نيست، لذا اصل برائت كيفرى به عنوان يك لهي تضمين براى رعايت اصل برابرى سلاحها و ايجاد تعادل و توازن قدرت ميان طرفين دعوا وضع ترديده است. (قربانى،

$(199: 1) 99$ بنابراين از جمله مهمترين مقتضيات اصل كرامت ذاتى انسان در قلمرو حقوق كيفرى شكلى حق بهرهمندى شهروندان از

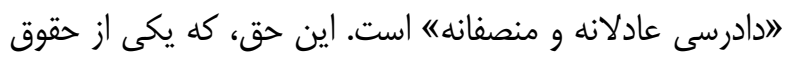
بنيادين بشر است، در بسيارى از اسناد بينالملى در سطح

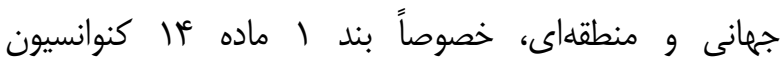
بينالمللى حقوق مدنى و سياسى و بند الماده و 1 كنوانسيون

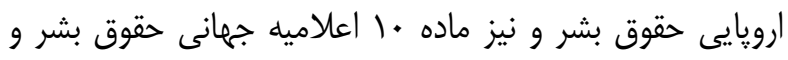
بند ب ماده 19 اعلاميه اسلامى حقوق بشر ييشبينى ترديده

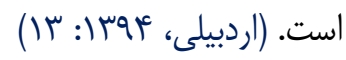

\section{ץ-Y-I- محدوديت استفاده از وكيل در يرتو اصول اخلاقى} در حقوق كشور آمريكا، متهم تحت اصلاحيه ششم قانون اساسى ايالات متحده حق احتيار وكيل را دارد. همرِنين يليس إنه موظف است ييش از آن كه شخص بازداشت شده را بازجويى إنى

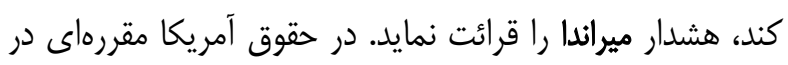

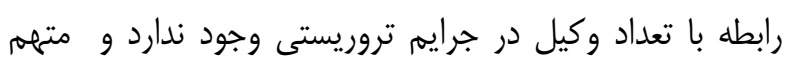

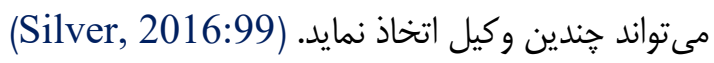
r-Y-r- جواز بركزارى دادرسى غير علنى و جايكاه اصول دادرسى منصفانه و عادلانه در آن از منظر آيين دادرسى اخلاقمدار، دادرسى علنى به عنوان يكى

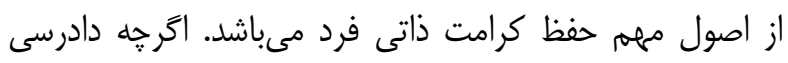

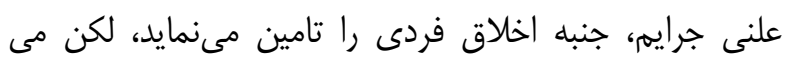


بوده را از اندازه حبسى كه دادكاه براى وى تعيين كرده،

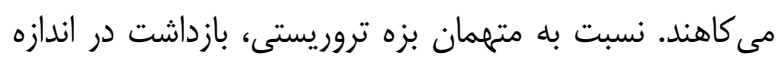

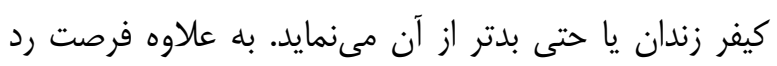

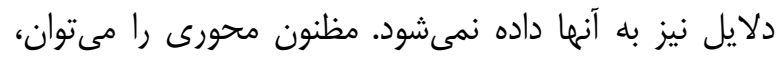
بدترين جهره قانونهاى ضد تروريسم دانست و اين ويثگى يادآور دوران اثبات بزه از رهخذر شانس و گمان است.

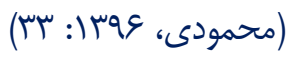
در حقوق آمريكا به منظور رسيدگى به جرايم تروريستى دو كروه از محاكم كه عبارتند از دادكاههاى كيفرى غيرنظامى و و

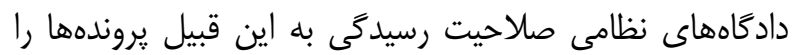
دارا مىباشند. جبهه حقوقى در جنى با تروريسم همراه با اختلاف نظر بوده است، در حال حاضر خندين يرونده عليه متهمين تروريسم در نظام قضايى ايالات متحده در دادگاههاى كيفرى غيرنظامى و دادگًاهاى نظامى كه توسط رئيس جمهور بوش در نوامبر |+. T تأسيس شده بود موجود است. برخى از يروندهها به دادكاههاى غيرنظامى و مابقى به دادَاههاى نظامى مىروند. آنجه كه تعيين مى كند كدام يرونده به يك دادكاه

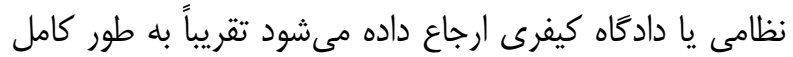
اختيارى و خودسرانه است و بستخى به ملاحظات آنى دارد. قانون ميهن يرستى، كَتمان سياست جنايى آمريكا را در نوع

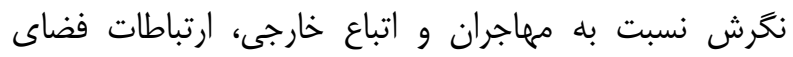
مجازى و فعاليتهاى تجارى و بانكى با تغيير و تحول اساسى مواجه ساخته و فرصت اعمال محدوديتهاى گستردهاى را در

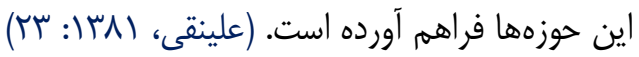
r-Y-Y- مؤلفههاى اخلاقى در ضبط مكالمات و كنترل نامهها در مراحل كشف جرم حريم خصوصى افراد از منظر اخلاقى، داراى حرمت و محدوديت براى ورود ديكران است. حريم منزل، دفتر كار، نامه نغارىها، ايميل، ييامى و نامههاى ادارى و شخصى و تماسهاى تلفنى، مصداقهاى حريم خصوصى هستند. يكى از

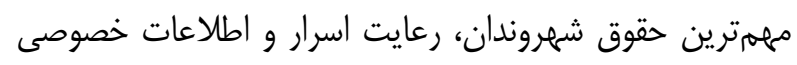
مردم، حفظ امنيت حريم خصوصى آنان است. از منظر اخلاقى شنود هر گونه مكالمه و كنترل نامه هاى افراد، مغاير با ارزش
مجازات قانونى آنها سلب حيات، قطع عضو و يا حبس ابد است. ب - هركاه محل اقامت، محل كسب و يا شغل متههم معين نباشد و اقدامات بازيرس براى شناسايى نشانى وى به نتيجه نرسد. پ - در مورد جرايم تعزيرى درجه پينج و بالاتر در صورتى كه از اوضاع و احوال و قرائن موجود، بيم تبانى يا فرار يا مخفى شدن متهم برود. ت - در مورد اشخاصى كه به جرايم

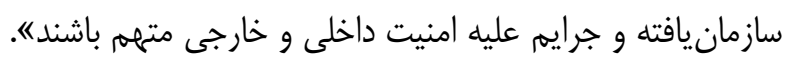
در حقيقت اگرجه جواز بازداشت خودسرانه قبل از اخطاريه از منظر اصول اخلاقى امرى مضموم است، لكن به اين دليل كه اصولاً متهمان جرايم امنيتى خاصه جرايم تروريستى به علت اصنى اينكه از قدرت تفكر و انديشه بالايى برخوردار مىباشند و به

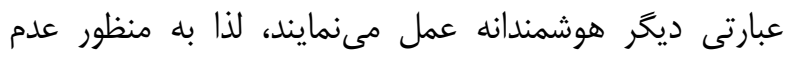

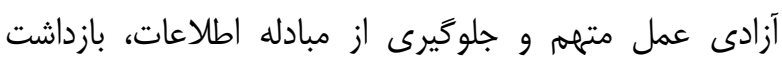

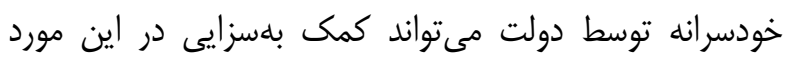
نمايد. بديهى است با توجه به موارد عنوان شده، خروجى عمل بازداشت خودسرانه توسط دولت، سودمندى جامعوى و حفظ اخلاق اجتماعى را در بر دارد.

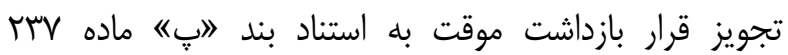

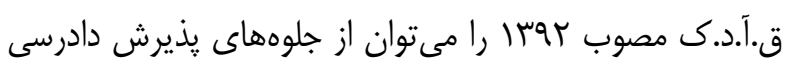
افتراقى درباره اعمال و جرايم تروريستى تلقى نمود هراكه در

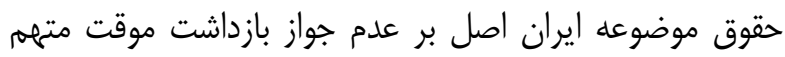
است (قسمت صدر ماده VIr) مخر در موارد استثنايى و خاص از جمله در جرايم عليه امنيت داخلى و خارجى با مجازات قانونى مانى

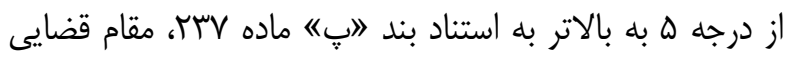

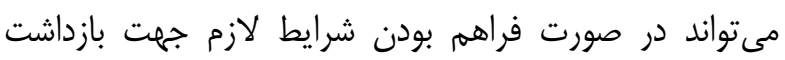

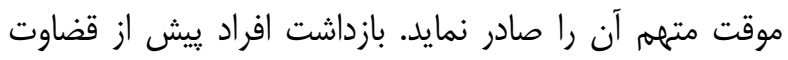

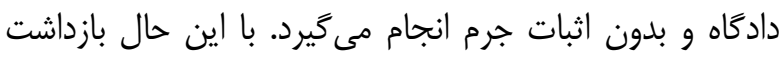
بخشى از روند سيستم عدالت كيفرى است. بازداشت موقت، سنخينترين قرار تامينى است كه براى بزهاى مهم صادر

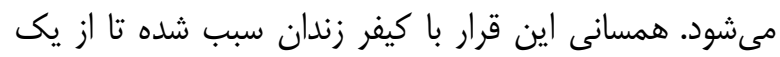

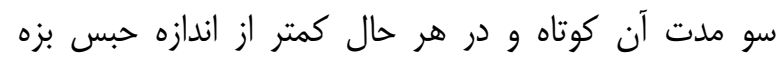

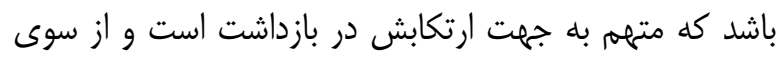
ديخر در صورت محكوم شدن متهه، مدتى كه در بازداشت 
جرايم امنيتى ضرورى است. بىشى سياست كيفرى موجود در راستاى محدوديت تماس تلفنى، اگرجه از منظر اخلاقى موجبات نقض حقوق متهم را فراهم مى آورد، لكن يكى از اثرات مفيد آن، حفظ سودمندى جامعه است.

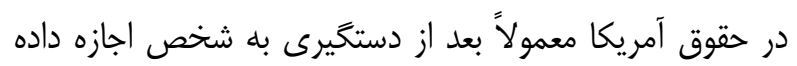

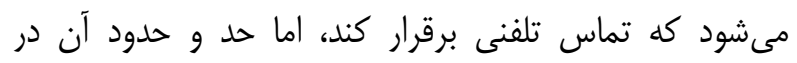
ايالات مختلف متفاوت است. براى مثال در ماده A شس قوانين

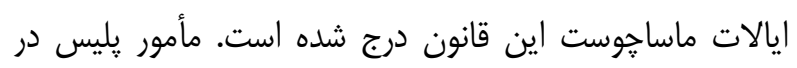
ايستخاه يا در محل بازداشتى كه در آن دستخاه تلفن موجود است بايد اجازهى تماس با هزينه خود فرد بازداشتى را بدهد.

(Dain, 2017: 90)

r-ץ-ז- امكان ينهان داشتن هويت شهود و مطلعان و جايكاه

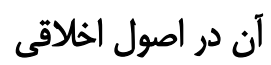
قانون خذار در مقام حمايت از شهود، اقدامات و تدابير غير كيفرى

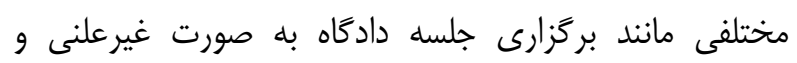

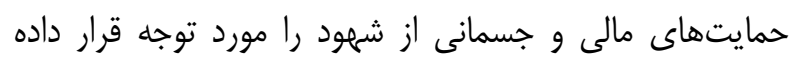

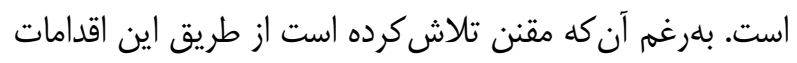

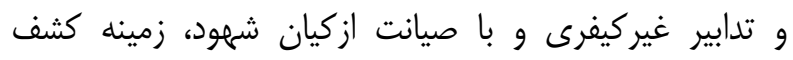

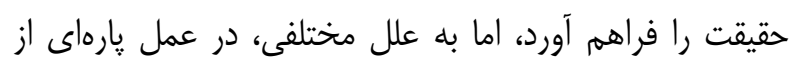

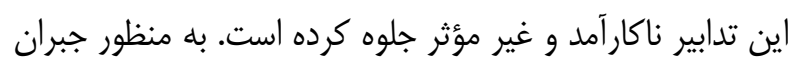

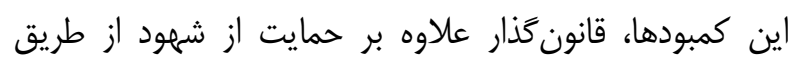
شيوهها و روشهاى غير كيفرى، به تدابير و اقدامات كيفرى نيز

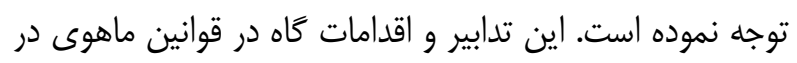
قالب تدابيرى جون جرمانغارى و كاه در قوانين شكلى به شيوههاى مختلف مانند بازداشت موقت متهم نمود يافته است. از جمله مواردى كه مقنن در حقوق ايران امكان ينهان داشتن

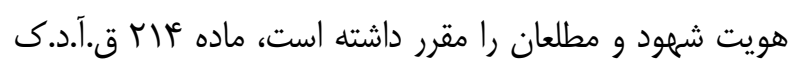
مصوب rqسا مىباشد كه اينكونه مقر داشته است: لاهر كاه بيم

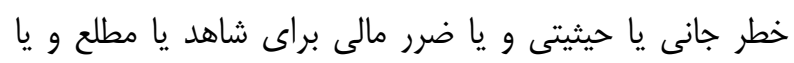

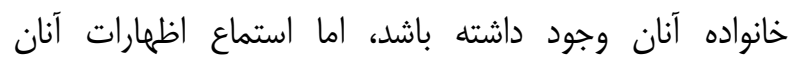

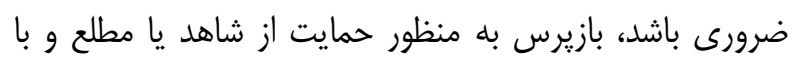

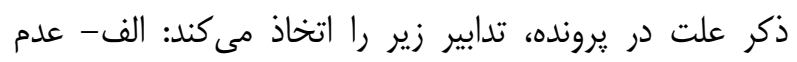

هاى اخلاقى بوده و امرى نايسند تلقى مى گردد. لذا در خصوص

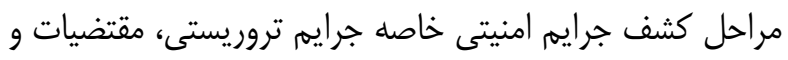
سودمندى جامعه اقتضاء مى نمايد كه مكالمات و نامههاى افراد جراد

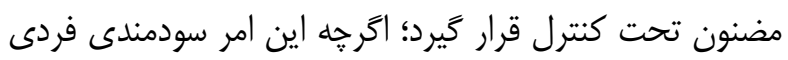
را در يى ندارد و از جمله عوامل نقض كننده حقوق افراد مىباشد، به ناجار در جرايم تروريستى بلواسطه مهرم بوده اين

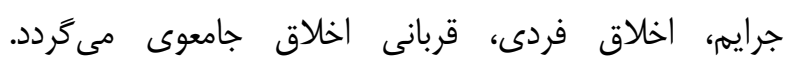

(Prentzas, 2006: 153) اصل فr قانون اساسى، ضبط و فاش كردن مكالمات تلفنى،

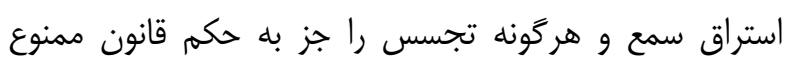
اعلام كرده است. بنابراين اصل بر عدم جواز كنترل ارتباطات تلفنى است. ييرو اين اصل قانونغذار در ماه •ما قانون آيين

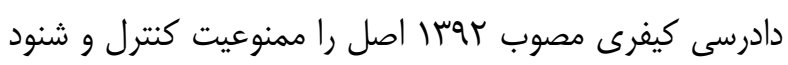
قرار داده است. مطابق اين ماده، كنترل ارتباطات مخابراتى افراد ممنوع است، مكر در مواردى كه به امنيت داخلى و خارجى مانى

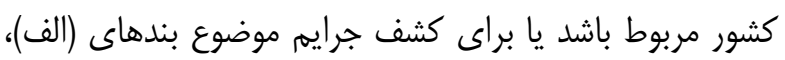
(ب)، (ب) و (ت) ماده (ץ+r) اين قانون لازم تشخيص داده شود. در اينصورت با موافقت رييس كل دادگسترى استان و با تعيين مدت و دفعات كنترل، اقدام مىشود. كنترل مكالمات

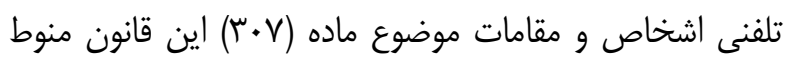
به تأييد رييس قوه قضاييه است و اين اختيار قابل تفويض به ماصد

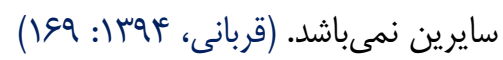
ץ-ץ-ץ- محدوديت تماس تلفنى و جايكاه آن در حقوق كيفرى نمى

اخلاقمدار يكى از موارد حفظ كرامت ذاتى انسانى و از جمله خصوصيات

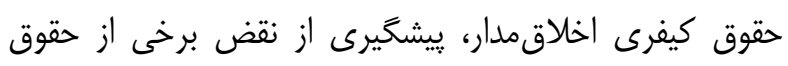

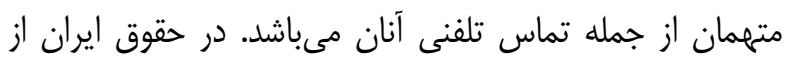

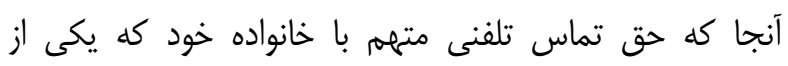

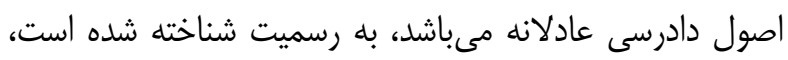

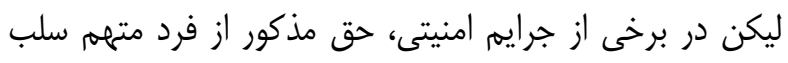

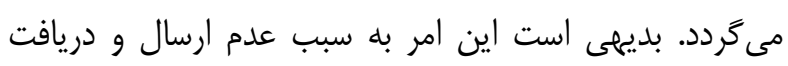

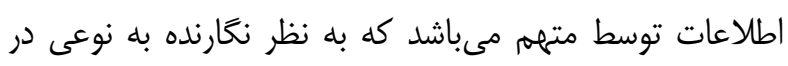


مشروعيت سياسى - اخلاقى خود را از دست خواهند داد. يكى

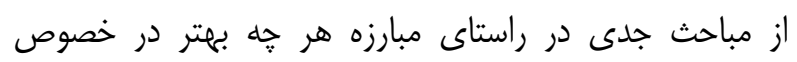
جرايم تروريستى كه مورد توجه قانونگذاران و دكترين حقوقى

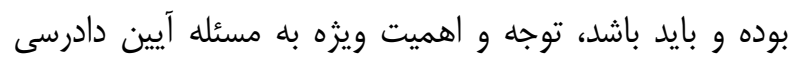

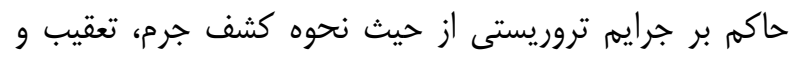

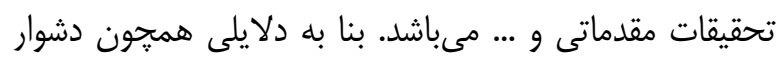
بودن دستخيرى تروريستها، همكارى نكردن آنها با مأموران دولت در صورت دستخير شدن، تهديد گواهان، تهديد دادرسان

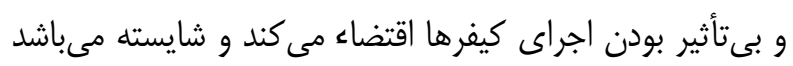

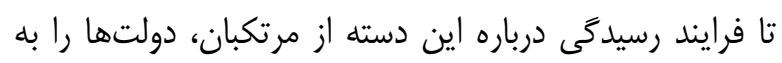
ييش بينى فرايند سخت تر و با شتابتر و سياست جنايى

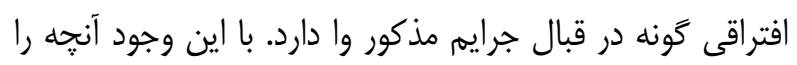
كه نغارنده در يى آن بوده است ياسخ به اين سوال است كه آيا

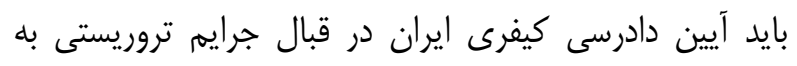

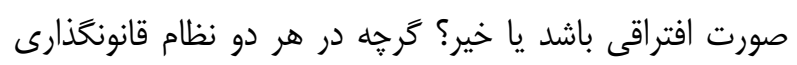
ايران و آمريكا، نمىتوان به طور قطع ادعاى وجود مقررات دادرسى افتراقى و خاص را همانند آيين دادرسى جرايم اطفال

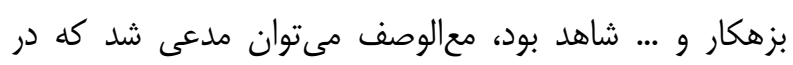

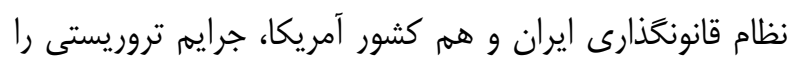
مىتوان تحت لواى جرايم بارز عليه امنيت (جرايم توأم با قتال

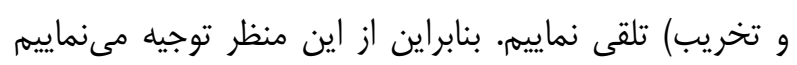

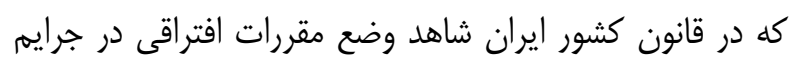
عليه امنيت داخلى و خارجى ازجمله جواز بازداشت موقت (بند

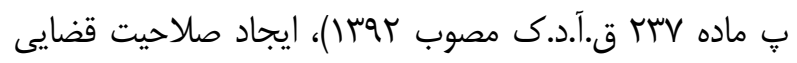
اختصاصى، امكان جلب قبل از ارسال احضاريه، محدوديت

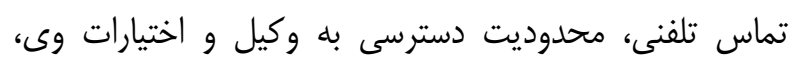

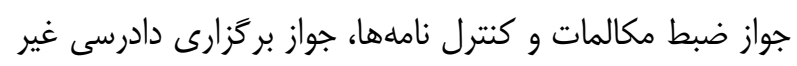
علنى مىباشيه و همجنين با بررسىهاى صورت گرفته، در

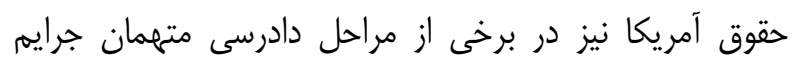
امنيتى، نوعى رسيدگى افتراقى به جشهم مى خورد.

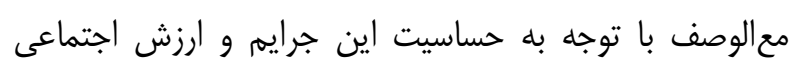

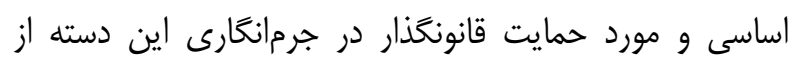
جرايم (تروريستى) و هم با توجه به حساسيت اين جرايم از
مواجهه حضورى بين شاهد يا مطلع با شاكى يا متهه. ب- عدم

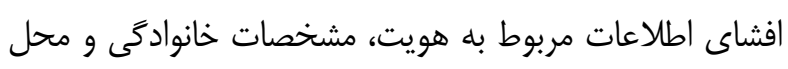

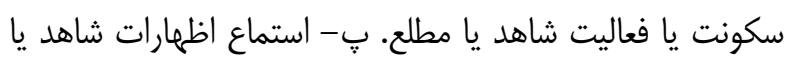

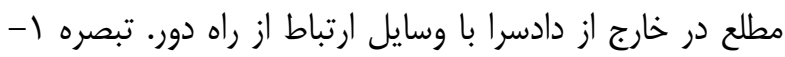
در صورت شناسايى شاهد يا مطلع حسب مورد توسط متههم يا متهمان يا شاكى و يا وجود قرائن يا شواهد، مبنى بر احتمال

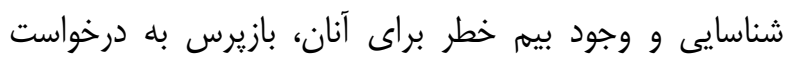

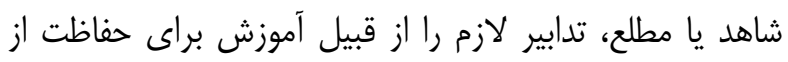
سلامت جسمى و روحى يا تغيير مكان آنان اتخاذ مى كند. ترتيبات اين امر به موجب آيين نامهاى است كه ظرف شئ لشعماه از تاريخ لازمالاجراء شدن اين قانون توسط وزارت دادگسترى موري تهيه مى شود و به تصويب رييس قوه قضاييه مىرسد. تبصره r- ترتيبات فوق بايد بلهنحوى صورت يذيرد كه منافى حقوق دفاعى متهم نباشد. تبصره ץ- ترتيبات مقرر در اين ماده و

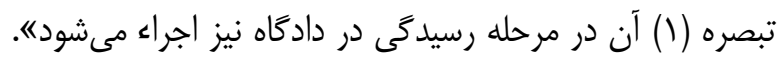
(Jazaiery, 2015: 64)

\section{نتيجه كيرى}

اصل كرامت انسانى و اخلاقى در قلمرو حقوق كيفرى شكلى لئى نيز از جايغاه والايى برخوردار بوده و داراى نقش محورى و و ونى بنيادين است. اين اصل در تضمين مشروعيت نظام دادرسى

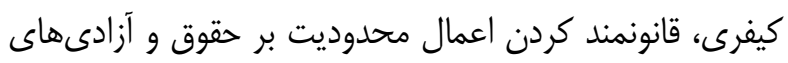
اساسى شهروندان، جهانى شدن حقوق كيفرى و تعديل حاكميت كيفرى مطلق و انحصارى دولتها داراى اهميت و

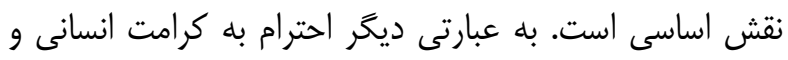
حقوق و آزادىهاى افراد از مبانى اخلاقى - سياسى مشروعيت يك نظام سياسى محسوب مى شود. نظريه مشروعيت اخلاقى -

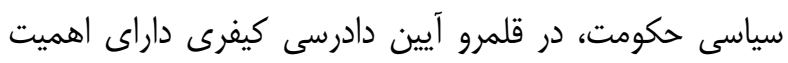
خاصى است جون قواعد آيين دادرسى كيفرى استفاده مستقيه

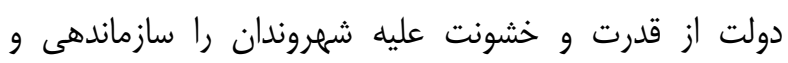
كنترل مى كند. اخر قواعد آيين دادرسى كيفرى ظالمانه و خودسرانه بوده و به دولت و مقامات اجرايى قانون يعنى

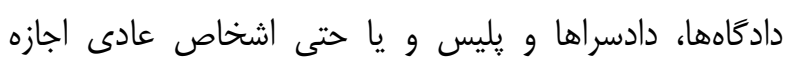

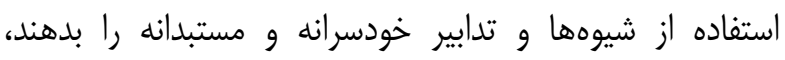


تعارض منافع: تدوين اين مقاله، فاقد هرگونه تعارض منافعى

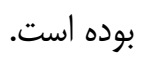

سهم نويسندكان: نغارش و نهايى سازى متن مقاله توسط

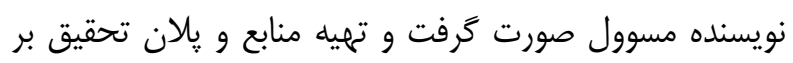
عهده نويسنده دوم بوده است.

تشكر و قدردانى: از تمامى كسانى كه در تهيه اين مقاله ما را يارى رساندند تشكر مىنماييه.

تامين اعتبار بزوهش: اين يزوهش فاقد تامين كننده مالى بوده
حيث ماهيت و آثار مخرب آنها و به منظور تأمين هرجه بهتر مصالح عاليه دولت، حكومت و ملت، اقتضاء دارد كه قانونخذار ايران اولاً در قالب قانون خاصى و يا فصل و عنوان خاصى را بـ اله

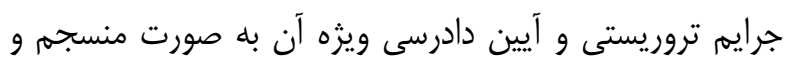

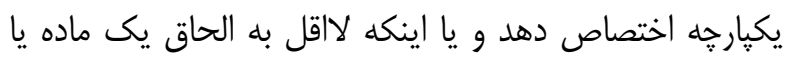

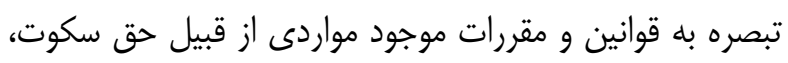
معكوس شدن بار اثبات دليل و ... را بخنجاند. ملاحظات اخلاقى: موارد مربوط به اخلاق در يزوهش و نيز امانتدارى در استناد به متون و ارجاعات مقاله تماماً رعايت كرديد. 
- Janda, K (2017). American Government in Global Politics. Vol 25. Massachusetts: The Challenge of Democracy.

- Jazayeri, M (2016). "Terrorism and Its International Instances". Criminal Law \& Criminology, 16(10):50-64.

- Kavanagh, A (2017). "Special Advocates, Control Orders, and the Right to a Fair Trial". Journal Compilation, The Modern Law review, 33(1): 89-121.

- Kittichisaree, K(2018). International Criminal Law. New York: Oxford University Press.

- Konani, S (2015). "The Interplay of Human Rights Standards and Security Criminal Policy in the Horizon of International Law with a Reflection on American Patriot Law". International Police Studies, 20(11):36-43.

- Plosi, S (2019). The Right of Suspects and Accuseds. New York: Oxford University Press.

- Prentzas, G (2006). Miranda Rights of the Accused. New York. NY: The Posen Publishing Group.

- Silver, A (2016). Prosecuting Terrorists after Septambr 11. Council on foreign Relations. New York: Tata McGraw-Hill Education.

- Stephenc, S (2015). "Two Lawyer one Client and the Duty to Communicate". University of new Hampshire law review, (5): 36-41.

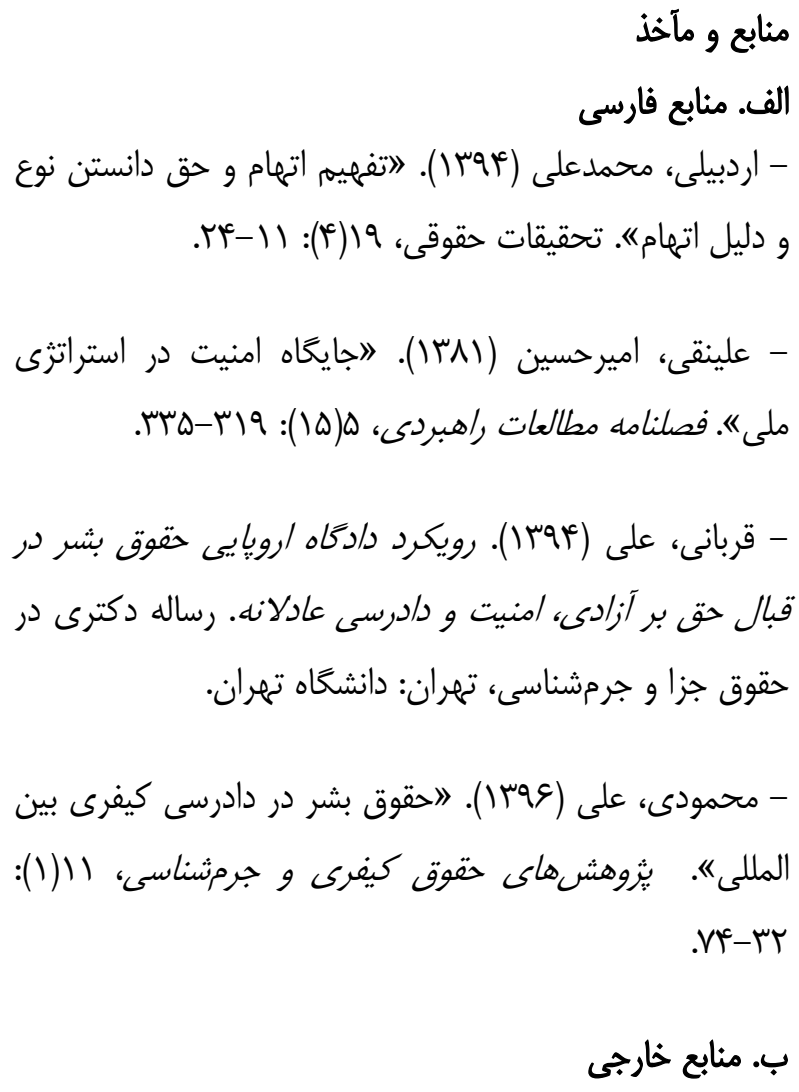

- Browntie, L (2016). Principles of Public International Law. California: Stanford University Press.

- Dain, C (2017). "The Protective Principle of International Criminal Jurisdiction". Plea Bargaining's Triumph j, 16 (102):88-114.

- Geoff, G (2015). Crimes Sans Frontiers: Jurisdictional Problems In USA code, The British Yearbook of International Law. New York: Council on Foreign Relations.

- Gordon, J (2016). Civil liberties VS. Civil Rights; on the Issues. Vol 27. Massachusetts: The Challenge of Democracy. 


\section{References}

- Alinaghi, A (2002). "The Position of Security in National Strategy". Strategic Studies Quarterly, 5(16):22-39. (Persian)

- Ardebili, M (2015). "Understanding the Accusation or the Right to Know the Subject and the Reasons of the Accusation". Journal of Legal Research, 19(4): 11-24. (Persian)

- Browntie, L (2016). Principles of Public International Law. California: Stanford University Press.

- Dain, C (2017). "The Protective Principle of International Criminal Jurisdiction". Plea Bargaining's Triumph j, 16 (102):88-114.

- Geoff, G (2015). Crimes Sans Frontiers: Jurisdictional Problems In USA code, The British Yearbook of International Law. New York: Council on Foreign Relations.

- Ghorbani, A (2015). The Case Study of the European Court of Human Rights on the Right to Freedom and Security and the Right to a Fair Trial. PhD Thesis in Criminal Law and Criminology, Tehran: University of Tehran. (Persian)

- Gordon, J (2016). Civil liberties VS. Civil Rights; on the Issues. Vol 27. Massachusetts: The Challenge of Democracy.

- Janda, K (2017). American Government in Global Politics. Vol 25. Massachusetts: The Challenge of Democracy.

- Jazayeri, M (2016). "Terrorism and Its International Instances, Lecture Series and Proceedings of the International Anti-Money
Laundering Conference". Criminal Law \& Criminology, 16(10):50-64. (Persian)

- Jazayeri, M (2016). "Terrorism and Its International Instances". Criminal Law \& Criminology, 16(10):50-64.

- Kavanagh, A (2017). "Special Advocates, Control Orders, and the Right to a Fair Trial". Journal Compilation, The Modern Law review, 33(1): 89-121.

- Kittichisaree, K(2018). International Criminal Law. New York: Oxford University Press.

- Konani, S (2015). "The Interplay of Human Rights Standards and Security Criminal Policy in the Horizon of International Law with a Reflection on American Patriot Law". International Police Studies, 20(11):36-43.

- Mahmoudi, A (2017). "Human Rights in International Criminal Proceedings, Commission of the Judiciary". Criminal Law and Criminology Resea, 11(1): 32-74. .(Persian)

- Plosi, S (2019). The Right of Suspects and Accuseds. New York: Oxford University Press.

- Prentzas, G (2006). Miranda Rights of the Accused. New York. NY: The Posen Publishing Group.

- Silver, A (2016). Prosecuting Terrorists after Septambr 11. Council on foreign Relations. New York: Tata McGraw-Hill Education.

- Stephenc, S (2015). "Two Lawyer one Client and the Duty to Communicate". University of new Hampshire law review, (5): 36-41. 